\title{
The Fundamental Need of Reform in Company Law in England: Parent Company's Liability for Debt of Insolvent Subsidiary
}

\section{Yining Long*}

University of Leeds, Leeds city, West Yorkshire, LS2 8EY, UK

\begin{tabular}{|c|c|}
\hline ARTICLE INFO & ABSTRACT \\
\hline Article history & \multirow{11}{*}{$\begin{array}{l}\text { Based on the fact that the parent company has actual control over the } \\
\text { subsidiary company, this paper analyzes the possibility of the parent com- } \\
\text { pany using the subsidiary company to seek benefits and damage the inter- } \\
\text { ests of creditors. Moreover, under the intangible protection of the current } \\
\text { limited liability system and the independent personality of the company, it } \\
\text { can "retreat". This is undoubtedly against the original intention of the es- } \\
\text { tablishment of enterprise groups and has great potential harm to creditors. } \\
\text { In addition, on the basis of the relief measures for the rights and interests } \\
\text { of the parent company caused by the bad behavior of the subsidiary, the } \\
\text { legal defects that should be carefully considered are determined. Consid- } \\
\text { ering whether there are other remedies that may have the same effect as } \\
\text { disclosure, some are more moderate than disclosure. With Britain's strong } \\
\text { caution about lifting the veil, a more moderate direction could be consid- } \\
\text { ered. }\end{array}$} \\
\hline Received: 1 October 2020 & \\
\hline Revised: 6 October 2020 & \\
\hline Accented. 9 October 2020 & \\
\hline & \\
\hline Published Online: 16 October 2020 & \\
\hline Keywords: & \\
\hline Reform & \\
\hline Limited liability & \\
\hline Parent company & \\
\hline Subsidray & \\
\hline
\end{tabular}

\section{Introduction}

${ }^{6} \mathrm{I}$ $\mathrm{t}$ is a common palace of commercial life today that businesses are conduct not only in the form of a single private or public company, but also in the form of a group of companies consisting of a holding company and a number of wholly owned subsidiaries and possibly sub-subsidiaries. ${ }^{,[1]}$ As a matter of English law, the limited liability system of the company is established by the limited liability law of 1855 . Besides, the introduction of company law of 1862 strengthened the status of independent corporate personality of the company. Therefore, limited liability also applied for corporate groups because of its separate personality. With the emergence of corporate groups structure, it is evident to see its advantages ${ }^{[2]}$. Replacing market relations with hierarchy inside of corporate groups can save transaction costs, particularly groups integration helps to internalize the positive externalities generated by exchanges ${ }^{[3]}$. Although the form of corporate groups makes huge progress in business world, it also brings problem that the possibility of holding company abuse limited liability system. For example, a parent company may undercapitalize its subsidiaries and use all the financing it provides to facilitate transactions that are opposite to its subsidiaries but beneficial to the group. When the parent company proves that the debt is equal, it is allowed to accept the management policy of the parent company at the expense of creditors. The moral effect of the bankruptcy claims of the parent company has not been examined, and the whole class of creditors are under constant threat ${ }^{[4]}$. The argument relating to parent company's liability for debts of insolvent subsidiary is a common subject in this field. In other word, under the protection of the principle of limited liability, it is no liability to credi-

*Corresponding Author:

Yining Long,

University of Leeds, Leeds city, West Yorkshire, LS2 8EY, UK;

E-mail:940466022@qq.com. 
tors of the subsidiary even if the parent company controls the subsidiary but not excessed control.

This paper from three parts to analyze why the law of holding company's liability for debts of insolvent subsidiary should be reformed urgently. In first part, it states the existing provisions base on principle of limited liability and separate legal personality. Furthermore, listing the disadvantages of existing law and unfair conditions which can prove that it is necessary to be reformed on existing law. The next part argues the possibility of abuse limited liability in the relationship of parent company and subsidiary. Combined with the provisions of the law on the rights of the parent company to its subsidiaries and the reality of injustice to prove the necessity of reform. The last part examines the remedies of limited liability - lifting the corporate veil. This part analyzes the disadvantages of remaining lifting the veil provisions and points out the strong entity law in the UK that the judge merely lifting the veil. Thus, there is no match between the existing system and the abuse of the system, so reform is urgently needed in this field.

\section{Limited Liability, Separate Personality and Existing Abuse Condition}

Not literally, parent has guardianship to children, subsidiary is entirely independent from parent company because of corporate separate personality. The concept of separate personality originated from the industrialization of Great Britain in the 19th century. At that time, the Victorian Government encourage entrepreneurs to carry out new business activities by eliminating the personal responsibility risks of directors, senior managers and shareholders of start-up business companies, so that quasi entrepreneurs would be more willing to participate in medium to highrisk business strategies and corporate diversification, which would lay the foundation for the prosperous economic future of Great Britain ${ }^{[5]}$. According to Company Law 2006, once a subsidiary is established, it has a separate legal personality directly. In addition, "the limited liability of the corporate shareholder is a traditional cornerstone both in Anglo-American corporation law and in the corporation law of the civil system. ${ }^{,[6]}$ Accordingly, in the text, this principle is normally illustrated by the notable case of Solomon v. Solomon Co., Ltd (Solomon case). The judgment and its interpretation of this case which issued by the Supreme Court has the guided meaning for the subsequent long-term judgment of limited liability cases. Solomon was supported by the Supreme Court in the final decision. The Supreme Court overturned the previous two judgments, which held that Solomon company is inde- pendent of the shareholder Solomon which is not affected by other factors: (i) other shareholders except Solomon are in family relationship. As for this fact, the lower two courts held that this is a one-person company in reality. However, the Supreme Court suggested that the Company Law does not exclude the shareholders with family relations from establishing a company; (ii) the establishment of Salomon company is not used to evade debts, because the establishment of the company is based on the good business conditions of Salomon, there is no debt evasion; (iii) the creditors should pay attention to the poor business conditions of the debt company ${ }^{[7]}$. The Solomon case is a milestone in the limited liability system. When limited liability applies to corporate groups, each company is protected from the obligations of other parts of the business. The limited liability of an enterprise has become the limited liability of every level in the enterprise. According to the traditional doctrine, this kind of corporation group has the same limited liability interests as the individual investors of Corporation in the history of common law. ${ }^{[8]}$ Therefore, as an independent individual in business, the subsidiary has responsibility for its own debts.

The separate legal personality of corporation is emphasizing with the confirmation of limited liability by Salomon case. "And in Adams v cape industries plc (1990) the court of appeal took the opportunity to examine at great length the way the courts have lifted the veil of incorporation in the past and narrowed significantly the way in which the courts could do so in the future. ${ }^{,[9]}$ In the case of Cape, the court examined fact with three factors. Firstly, the court examined the major "single economic unit" where group structures were treated as being a single entity ${ }^{[10]}$. The second factor is the point of "corporate veil" where the subsidiary is the façade concealing the true facts ${ }^{[11]}$. whether the subsidiary company is actually only an agency company of the parent company. The third one is the argument of "agency" that the actions of the subsidiary would bind the parent ${ }^{[12]}$. The court rejected the argument based on three circumstances in which the veil of incorporation can be lifted "Thus as none of the three veil-lifting categories applied Cape was not present in the USA through its subsidiaries."

According to the three standards left by the judgment of the Cape case, the limited liability system is likely to become the protect shade of the conductions that the parent company damages the interests of subsidiaries, creditors or engages in other illegal activities. Once the abuse emerged, the creditors of subsidiaries will be the most seriously damaged party. Moreover, it does not exclude that the parent maliciously makes the subsidiary into insolvent procedure. For example, collusion with the parent 
company, maliciously transfer the assets of the subsidiary company; in the case of few assets, maliciously use the means of separating the share dividend. Return the starting point of the establishment of company limited liability system, it is service for reducing the debt burden of large enterprises in the market, so as to play a supporting role better in business. However, the existing cases of abuse of the limited liability system indicates that it will violate the original intention of the establishment of the system if the system remain unchanged. The law will not advocate the behavior of evading responsibility and escaping debt, but there are many facts that parent companies make use of subsidiaries to make profits and escape debt, so the field needs to be reformed.

\section{Parent Company and Subsidiaries}

Under the law, the parent company has considerable latitude to take harmful actions against its subsidiaries. In the company group, although the subsidiary has the formal independent legal personality, it should obey the arrangement of the parent company in the actual operation and serve the overall interests of the group company, which makes the independent legal personality of the subsidiary empty. For example, the regulation of Company Law 2006 the acquisition or holding of another company's equity, of the contractual arrangement of the control right between companies, of the centralized exercise of the company's voting right, and of the chain directors are all typical provisions of the company law affirming the company's control. On the one hand, the control of the parent company over the subsidiary is mainly lies in the proportion of shares and the voting right of the resolution matched by the proportion of shares. "Power is used in a group of companies to ensure that each member complies with the wishes of the controller, usually the parent. The way parental control works can be divided into the legal and the 'factual' forms." Legal form indicated on the provision that the parent company has compulsory power to dismiss or remove the directors. In addition, the legal voting right of the parent company enables it to control the contents of the articles of association of the subsidiary and the articles of association of the board of directors. The parent company also exercises "extralegal" or "de facto" control over its subsidiaries by exerting pressure or influence to determine the choice of directors. As for "factual" form, the parent company truly controls the activities of the subsidiary by controlling its directors. As a trustee, the director's duty is to exercise a certain degree of prudence to the subsidiary, taking the benefit of the subsidiary as the management goal. When the parent company's behavior is superior to the director's obligation to the subsidiary company, the parent company may intervene in the subsidiary company's affairs by preventing the director of the subsidiary company from performing his duties. But for the determination of "interference", there must be enough causality to produce the duty of care. It can be said that the behavior of directors must be directly affected by their parents. On the other hand, the parents have the right to choose the source of funds for the subsidiary. The capital of a subsidiary usually consists of debt and equity. Debt financing is usually obtained from the parent company or bank in exchange for commercial paper with different degrees of security. Equity financing is to raise funds by issuing shares and these shares have different rights and usually give the holder a certain degree of control.

As the conventional legal view of the parent-subsidiary relationship in England treats the parent as no more than a shareholder, shareholders have no liability to anyone expect to the extent and manner provided. Besides, the Company Office Association (COA) recognizes that the subsidiary is establishes the basic principle of "legal personality" according to the general law and believes that the Solomon principle also applies to the enterprise group, though it is the product of the parent company. Similarly, parent company as a majority shareholder who has no liability for debts to its subsidiary. The harmful act of the parent company itself will not cause any litigation, thus affecting the claim right of the parent company in the liquidation of the subsidiary. In fact, with the exception of remedies related to fraud, capital maintenance and illegal and fraudulent transactions, creditors of subsidiaries have no recourse to the parent company or other group companies due to the principle of independent personality. Parent companies can use subsidiaries outside these relatively independent boundaries "for their own benefit". They can manage its affairs as they wish, as long as they acted intra vires and in good faith. Therefore, the parent company was excluded the liability of the parent company for the debts of the subsidiary as an outsider only if they are in good faith, ignoring that the benefits the parent company obtained in the group structure came from the convenience of controlling the subsidiary company. "Just as an individual can act like a fool so too can a company. "Under the limited liability, the parent company suggest those who do business with its subsidiaries assess the economic situation of subsidiaries by themselves. Moreover, it is incomprehensible that "if the subsidiary is a success profit will be forthcoming to the parent but if it fails the parent is allowed to prove its debts and be treated pari passu with other creditors." The parent company has the possibility to operate the directors of the subsidiary company, but the supporting power relief does not provide any 
direct responsibility between the parent company and the subsidiary company.

The law in England fails adequately to attribute any responsibility to a parent in this role instead of the large scope of autonomy in legal interpretation that the parent company can use. However, it is the possibility of power abuse. The abuse of power is directly proportional to the size of interests. A practical economic theory held that the use of control is for the best interests of the parent rather than the subsidiary." For more than 14 years the recommendations of the Cork Report concerning the potential for abuse of the parent-subsidiary relationship and intercompany indebtedness have fallen on deaf legislative ears." Reform proposals to date have been conspicuously deficient.

\section{The Need of Reform on Remedy Method of Limited Liability}

As a remedy means of abusing limited liability, the existing uncovering system is far from the ideal effect, "the starting point in group structure veil-lifting cases has always been that Salomon doctrine applies unless there are other reasons for lifting the veil." Since the decision of the house of Lords in Salomon v. Salomon limited, it has number of cases for courts to peep behind the company's veil. However, it is difficult to find a unified theory to uncover the company. The creation of "unveiling the company" was derived from the case of U.S. v. Milwaukee refrigerator Transportation Co in 1905. In the judgment of the case, judge Sanborn made a classic statement on the principle of unveiling the company:

"... as far as the general rules are concerned, the company should be regarded as a legal person and have an independent personality unless there are sufficient reasons to the contrary; however, if the corporate characteristics of the company are used as a tool to damage the public interest, legalize illegal acts, protect fraud or defend crimes, then In law, the company should be regarded as a combination of several persons with no right and ability."

"Unveiling the company" is an important method to deal with the responsibility of parent company to subsidiary company in common law countries. That is, according to the specific facts in the specific legal relationship, the independent personality and limited liability of the company and its shareholders are denied, which is also the core of the theory. In order to prevent the abuse of the company's independent personality and protect the interests of creditors and social public interests. As an exception and supplement to the limited liability of shareholders, it corrects and balances the personality independence and limit- ed liability required by the traditional legal person system.

There are other methods which define the liability to subsidiaries that the parent has, except the piercing veil system. Such as the system of fraud and improper transaction. Although existing systems try to correct the abuse of corporate form, they will never discuss the control relationship between parent company and subsidiary company for the benefit of creditors with a minimum standard of conduct that deters abuse of this power. The futures of Limited liability and separate personality are so fundamental that any changes to the status quo would result in widespread confusion and uncertainty. Therefore, the focus of the reform must be to seek both other doctrines that support the phenomenon of corporate groups and recognize the superiority of Solomon v. Solomon Co.

The British court is particularly cautious to unveiling corporate veil with a strong entity law. It strictly complied the Solomon principle within the scope of enterprise groups. This was reflected in the Adams case, where the COA argued that, unless permitted by law, the court would not ignore the corporate veil when required by justice. For instance, in Okpabi v RDS case, the court insisted on the judgment that not lifting the corporate veil, though the huge damages and environmental pollution caused by the company. In the Re Augustus Barnett \& Son where an unsuccessful attempt was made to make a parent liable for the debts of its subsidiary under the fraudulent trading section of Insolvency Act 1986, s.213. Most business activities are highly integrated across entities within a group. The strong entity law could be unfair to the involuntary creditors of an insolvent subsidiary because the UK courts are reluctant to hold a solvent parent responsible for the debts of its subsidiaries. Although the court has already shown its attitude towards the tort liability that the parent company has in Chandler v Cape case, it is conspicuously that limited liability system is powerful. In England, due to the strict priority rules and the legal effect of giving equal distribution rules, the legislative system does not allow to modify the relationship between claims and debts. Second, not recognize the damage that the subsidiary may suffer in the hands of the parent company. The reason for this is that the role of the parent company as the controller of the subsidiary is not recognized. Third, to insist that the company in a group is the legal paradigm of atomism, each of which has its own different creditors and a long history.

This deficiency in the law can be made up by a legislative measure. There is another way to solve the problem of responsibility attribution between parent and subsidiary companies, focusing on the supervision of parents' control over subsidiary companies, rather than just unveiling the 
veil. This subordination remedy is adopted to balance the rights and interests among the creditors of the bankrupt subsidiary according to the former behavior of the parent company to the subsidiary company. Here, the conflicting interests are essentially the interests of the parent company and other creditors. When bankruptcy is imminent, if the interests of external creditors are found to be unfair, the interests of external creditors shall prevail over the interests of the parent company. It is necessary to review all previous actions of the parent company as controller when necessary.

For the problems of debt, the principle of equity can be introduced in system, which provides a set of legal basis for reference and improvement. It can be observed that, lifting the veil is an uncertain and extreme remedy in the UK that the courts will refuse in most cases. The introduction of a broad concept of equity can solve some of the shortcomings of the rigid priority system. Meanwhile, it can be recognized that the concept of "unfair behavior" is based on the determination of the minimum standards of behavior that a parent company should abide by when dealing with its subsidiaries. If the parties are to benefit from a business transaction or association, they must act in a way that balances their own interests with fairness, honesty and legitimacy. Subordinate remedies will allow for the evaluation of the parent-child relationship and give creditors the opportunity to claim on the assets of the parent company without replacing Solomon. Putting off debt to equity is far less drastic than lifting the veil.

\section{Conclusion}

This paper starts with the fact that the parent company has the actual control power over the subsidiary, analyzing that the parent company is likely to make use of the subsidiary company for profit and damage the creditor's interests. Moreover, it can "retreats" under the intangible protection of the current limited liability system and the independent corporate personality of the company. This is undoubtedly a violation of the original intention of the establishment of enterprise groups, which has great potential harm to creditors. Besides, based on the remedial measures of the parent company's rights and interests arising from the harmful acts of the subsidiary company, the deficiencies in the law that should be carefully considered are determined.

Considering whether there are other relief measures that may have the same effect as uncovering, and some are more moderate than uncovering. Because of the strong caution about lifting the veil in the UK, it can be considered in a more moderate direction. Thus, the standard of conduct should be an "open" concept, stipulating the obligation of fair or faithful management, and combining with the mechanism of allowing equal exceptions.

\section{References}

[1] Adams v Cape Industries Plc [1990] Ch. 433 (CA (Civ Div)) .

[2] Alan Dignam and John Lowry, Company Law (10th edn, OUP 2018).

[3] Blumberg PIJJCL, 'Limited liability and corporate groups' (1985) 11573.

[4] Chandler v Cape Plc [2012] EWCA Civ 525.

[5] Hofstetter KJI and Quarterly CL, 'Parent responsibility for subsidiary corporations: evaluating European trends' (1990) 39576.

[6] Rahman MRJIJOH and Science S, 'Holding Company Liability for Subsidiary Company-A Critical Analysis under UK Companies Act 2006' (2013) 1392.

[7] Re Augustus Barnett \& Son Ltd [1986] BCLC 170.

[8] Okpabi v Royal Dutch Shell [2018] EWCA Civ 191.

[9] Ong-Wee PGJMLR, 'Corporate Personality-A Step Closer to Reality’ (1990) 32355.

[10] Salomon v Salomon \& Co Ltd [1897] A.C. 22 (HL).

[11] Schulte R, 'Corporate Groups and the equitable subordination of claims on insolvency' (1997).

[12] U. S. v. Milwaukee Refrigerator Transit Co., (1905) 142 Fed. 247. 